\title{
Developing A Nigerian Local Government Through Economic Gardening: A Roadmap
}

\author{
Umaru Zubairu' ${ }^{1},{ }^{1}$ Ruth Kolo, ${ }^{1}$ Hadiza Umar, ${ }^{1}$ Asmau Usman, ${ }^{1}$ Yakubu Mustapha, ${ }^{1}$ Jaafar \\ Umar \\ 1 -Department of Entrepreneurship and Business Studies, Federal University of Technology \\ Minna, Nigeria. \\ uzubairu@gmail.com
}

\begin{abstract}
Economic Gardening is an innovative economic development strategy whereby local businesses are fostered and encouraged, and the skills of local workers are upgraded. Since its inception in Littleton, Colorado in 1989, this concept has been put forward by various scholars as a viable and more sustainable economic development strategy than the traditional business attraction strategy. Various implementation experiences have provided further evidence of its effectiveness in improving the quality of life of the inhabitants of a community. This paper charts a roadmap for the development and future implementation of an economic gardening strategy for a Nigerian local government whose officials have shown an interest in adopting such a strategy. A seven-step process was adopted from a review of economic gardening scholarship: 1) Working hand-in-hand with local government officials and other stakeholders, 2) Identifying the community's assets, 3) Developing a collaborative effort amongst all stakeholders, 4) Developing a clear and transparent operating agreement, 5) Identifying the key targets for services, 6) Developing an effective way to deliver these services, and 7) Communicating regularly with the community so as to gain and retain their support. A lack of political will and a lack of adequate infrastructure were identified as the two biggest obstacles to the successful implementation of the economic gardening strategy in the local government. The first obstacle was mitigated by the fact that it was the local government officials who approached our team to develop the strategy, whilst the second obstacle was mitigated by a proposal for the development of a solar farm within the local government via a public-private partnership with an international solar firm. It is hoped that a successful implementation of this strategy will improve the lives of the inhabitants of the local government and serve as an example for other Nigerian local governments.
\end{abstract}

Keywords: Economic gardening; Local government; Economic development; Entrepreneurship; Nigeria.

\begin{tabular}{|c|c|c|}
\hline Received & Revised & Published \\
\hline 11 January 2019 & 11 February 2019 & March 2019 \\
\hline
\end{tabular}

\section{INTRODUCTION}

Economic Gardening is an innovative economic development strategy whereby local businesses are fostered and encouraged, and the skills of local workers are upgraded (Kirkpatrick \& Davidson, 2018). In a nut shell, it follows the following process: Locate local entrepreneurs, and then equip them with the information, strategies and resources they need to stay and grow in the 


\section{THE SPIRIT OF SOCIETY JOURNAL}

International Joumal of Society Development and Engagement

ISSN : 2597-4777 (Online) - ISSN : 2597-4742 (Print)

This work is licensed under a Creative Commons Attrib ution-ShareAlike 4.0 International License.

community. The long-term results are sustainable economic development and improvement in the quality of life of the local community (Adikhari et al., 2018; Cowell et al., 2018; Overbey, 2019). This is exactly what Nigeria's local governments need, especially considering the fact that their development has been neglected for decades largely due to entrenched corruption amongst the political leadership of these local governments. This paper outlines the development of a roadmap that will hopefully facilitate the development and implementation of an economic gardening strategy in a Nigerian local government whose political leaders have shown an inclination to actually fulfill their mandate of improving the quality of life of their citizens. This willingness was manifested in the fact that these political leaders were the ones to approach our team with a desire to undertake such a vital endeavor.

In the state where this local government resides, the previous administration had brazenly violated the constitutional autonomy of local governments by preventing them direct access to their monthly financial allocation from the Federal Government for eight years. The previous administration made arbitrary decisions as to how much each local government would get from these allocations. The result was that for eight years the political leadership of the local governments were simply figure heads with absolutely no power to implement any real initiatives that would improve the lives of their constituents. The new administration has thankfully done away with this draconian policy, and local governments will have full control as to how to utilize these resources. Additionally, the state Governor has encouraged local government officials to find innovative ways to maximize their internally-generated revenues. It is against this backdrop that the Chairman of one of the local governments approached our team regarding the development of an economic gardening strategy to enhance the lives of his constituents.

The rest of the paper proceeds as follows: first, a literature review of economic gardening scholarship is presented, and then the roadmap which will serve as a guide for the development and implementation of an economic gardening strategy is presented with full consideration given to the peculiarities of the local government in question. Finally, a conclusion is presented.

\section{LITERATURE REVIEW}

The review of economic gardening scholarship revealed two broad streams of research: the first stream included papers advocating economic gardening as the best and most sustainable way for local government economic development, and the second stream presented case studies of the implementation of economic gardening strategies in various parts of the world. The key observations from these two streams are presented below.

\section{Stream 1: Reasoned arguments on why Economic Gardening is an effective and sustainable strategy for local economic development as compared to the tradition business attraction strategy}

Traditional strategies of business attraction whereby large corporations are incentivized to relocate to a local community leads to these corporations exploiting the resources contained in that community without regard for the sustainability of such exploitation (Lamb \& Sherman, 2010; Wang, 2018). This is because these corporations are not headquartered in these communities, and are only there for what they can get (Conroy et al., 2016; Peter, 2017). Economic gardening, 


\section{THE SPIRIT OF SOCIETY JOURNAL}

International Joumal of Society Development and Engagement

ISSN : 2597-4777 (Online) - ISSN : 2597-4742 (Print)

This work is licensed under a Creative Commons Attrib ution-ShareAlike 4.0 International License.

on the other hand, fosters the growth of local businesses spawned in the local community, and these businesses are more likely to engage in sustainable usage of resources as they and their families live in these communities, and would want to be able to do business there for a long time without damaging the prospects of future generations (Markley et al., 2015; Miles \& Morrison, 2018).

Secondly, Economic gardening leads local business to form a strong network whilst developing a symbiotic relationship whereby they work hand-in-hand to grow their businesses and help develop the local economy in a steady and sustained manner (Hancks, 2012; Braun et al., 2014). In contrast, big businesses that relocate to a local community usually disrupt such local networks, and because these big businesses normally don't stay long, it creates an environment where new complimentary local networks are difficult to form (North, 2014; Norris, 2019)

Thirdly, business attraction is an extremely competitive economic development strategy, with only a few big businesses willing to relocate, and thousands of local governments competing for these few businesses (Yi Hsieh, 2011; Arku, 2014). These local governments are thus forced to offer exceedingly generous incentives to attract these big businesses, and this is often detrimental to the long-term economic development of the local governments (Ha \& Feiock, 2012; Carvalho et al., 2018). Minchin (2018) gave an example of a local government in Alabama which offered incentives amounting to $\$ 200,000$ per job created to Mercedes to open a plant in its community; they still lost the bid. Another example was that of the town of Warren, Michigan which offered General Motors a 30-year tax abatement incentive to relocate its headquarters from Detroit to Warren; the bid was also ultimately unsuccessful (Lin et al., 2017). Some local governments that have successfully attracted such companies with these incentives unfortunately experienced huge unemployment and inflation rates because these companies left much earlier than was expected (Adua \& Lobao, 2015; Leviten-Reid \& Parker, 2018; Cleave et al., 2019).

Fourthly, for those few local governments which successfully attract big businesses, local businesses are often driven out of business as they do not possess the financial might to compete with these big businesses (Engbers \& Rubin, 2018; Whittemore \& BenDor, 2018). This implies that these local governments are actually harming the long-term economic development of their community (Zeier et al., 2018). This is because local SMEs create the majority of jobs in their localities all around the world (Perera, 2015; Cecere \& Mazzanti, 2017; Boskov, 2018).

Fifthly, local governments in a rural setting are even at a greater disadvantage than those in an urban setting (Hultquist et al., 2017; Monnat \& Brown, 2017). This is because they often do not possess the necessary infrastructure or financial resources to even begin to attempt to attract big businesses to relocate to their communities (Cordoba, 2019; Shetty \& Vasanthi, 2019). For these rural local governments, they either adapt economic gardening principles or do nothing (Corbett, 2015; Adhikari et al., 2018).

Finally, there is tangible evidence of the success the economic gardening approach in developing cities, as evidenced by the Littleton Experience (Assenza, 2016). The first application of the concept of "economic gardening" was initiated by Chris Gibbons in the city of Littleton, Colorado in 1989 (Taabazuing et al., 2015). The city had two main economic problems: the first was that most jobs in the city were from one company, Martin-Lockheed, an aerospace company 


\section{THE SPIRIT OF SOCIETY JOURNAL}

International Joumal of Society Development and Engagement

ISSN : 2597-4777 (Online) - ISSN : 2597-4742 (Print)

This work is licensed under a Creative Commons Attrib ution-ShareAlike 4.0 International License.

(Assenza, 2016). The second was their reliance on the traditional business attraction strategy which had yielded very little positive results (Assenza, 2016). When Martin-Lockheed started laying off thousands of workers, the city of Littleton had to think outside the box to survive. They developed a development strategy based on three policies: 1) improve the city's basic infrastructure, 2) improve the quality of life of the inhabitants by providing open spaces, hiking trails and hosting community events and 3 ) facilitate the growth of local businesses by providing them with valuable, real-time financial and technical information and creating local networks of similar businesses and suppliers. After a three year bedding-in period, the program started to yield impressive results, with 12,000 new jobs created over the next decade, an $8 \%$ annual job increase as compared to a $3 \%$ increase in other cities in Colorado (Gibbons, 2010).

\section{Stream 2: Implementation Experiences}

The studies reviewed in this stream provided case studies of cities and communities that have successfully implemented an economic gardening strategy: from US cities such as Oregon (Barrios \& Barrios, 2004; Roberts et al., 2012), Michigan (Leavitt et al., 2010), Kentucky (Robbins \& Allen, 2015), Florida (Minter, 2012), and Indiana (Minter, 2012), to other countries as far as Australia (Blackwell \& Coltman, 2007; Braun et al., 2014) and Japan (Yamamoto, 2007). Regardless of location, in order to implement a successful economic gardening strategy, generally, some combination of the seven steps described below needed to be taken:

1. Working hand-in-hand with local government officials and other stakeholders:

The cooperation of local government officials and other key stakeholders like chambers of commerce and other business organizations is crucial for the success of an economic gardening strategy. It is important that their opinions be extensively sought on the most effective ways to implement such a strategy. All stakeholders must share the same vision of the implementation strategy and ultimate objective of the economic gardening strategy (Barrios \& Barrios, 2004; Yamamoto, 2007; Leavitt et al., 2010; Minter, 2012; Roberts et al., 2012; Robbins \& Allen, 2015)

2. Identifying the community's assets:

A comprehensive baseline study of the community's assets must be carried out so that a proper roadmap can be developed on the best way to achieve an effective economic gardening strategy. There should be a detailed inventory of the community's human capital, quality of life amenities, as well as the natural resources available that can be sustainably exploited. It is also important to identify existing organizations that can serve as valuable partners in implementing the strategy (Barrios \& Barrios, 2004; Yamamoto, 2007; Leavitt et al., 2010; Girdwood \& Girdwood, 2011; Braun et al., 2014; Robbins \& Allen, 2015).

3. Developing a collaborative effort amongst all stakeholders:

It is crucial that a committee be formed that is made up of important stakeholders. These committee enables these stakeholders to work hand-in-hand and spearhead the economic gardening strategy. Without collaboration and a sense of ownership amongst these stakeholders, an economic gardening strategy is doomed to fail (Barrios \& Barrios, 2004; 


\section{THE SPIRIT OF SOCIETY JOURNAL}

International Joumal of Society Development and Engagement

ISSN : 2597-4777 (Online) - ISSN : 2597-4742 (Print)

This work is licensed under a Creative Commons Attrib ution-ShareAlike 4.0 International License.

Yamamoto, 2007; Desplaces et al., 2009; Leavitt et al.,, 2010; Leavitt, Leavitt et al., \& Fails, 2010; Girdwood \& Girdwood, 2011; Minter, 2012; Roberts et al., 2012)

4. Developing a clear and transparent operating agreement:

The committee formed in the third step must develop a transparent operating agreement which clearly lists key tasks in the economic gardening strategy and which party is responsible for fulfilling each task. Such tasks include funding responsibilities, decisionmaking responsibilities, service delivery responsibilities, and impact assessment responsibilities (Leavitt et al.,, 2010; Pochert, 2010; Girdwood \& Girdwood, 2011; Minter, 2012; Roberts et al., 2012).

5. Identifying the key targets for services:

The businesses in the community that are the target for the economic gardening strategy must be clearly identified and known by all members of the committee. The kind of businesses identified will shape the strategy adopted. However, regardless of the specific strategy adopted, the services offered usually combine three basic building blocks: Information, Infrastructure and Connections. Businesses are usually one of three kinds: start-ups, lifestyle businesses (local mom and pop stores) and growth companies (businesses that offer goods and services to both local and external clientele). Growth companies are usually the primary focus of economic gardening strategies because prior research has shown that they create the greatest economic impact due to the fact that they bring into the community funds from outside (Blackwell \& Coltman, 2007; Leavitt et al.,, 2010; Pochert, 2010). Although the life-style businesses do not have as great an impact on the economy of the community, they usually represent the majority of existing businesses in the community and perform the important job of recirculating wealth within the economy. For this reason, they should not be ignored in an economic gardening strategy. Additionally, there is no reason why a life-style business cannot be transformed into a growth business with the right strategy (Leavitt et al.,, 2010; Roberts et al., 2012; Robbins \& Allen, 2015)

6. Developing an effective way to deliver these services:

It is essential that qualified personnel are secured to deliver the services that the identified businesses need. For example business coaches and trainers might be needed if local entrepreneurs have to be trained in basic, intermediate and advanced business skills like accounting and marketing research. Funding sources have to be identified that will cater for the expansion needs of local business; sometimes government schemes tailored for small businesses can be taken advantage of, such as small business loans or micro-credit programmes. Key infrastructure must be provided that make the community an enjoyable place to live and do business in. Forming a cooperative amongst similar businesses can also be a useful way of pooling resources and expertise together in order to form effective and synergistic relationships amongst these businesses. As always, the delivery system should take into consideration the peculiarities of the local community involved in the economic gardening strategy (Yamamoto, 2007; Leavitt et al.,, 2010; Leavitt et al., 2010; Pochert, 2010; Roberts et al., 2012; Braun et al., 2014; Robbins \& Allen, 2015). 


\section{THE SPIRIT OF SOCIETY JOURNAL}

International Joumal of Society Development and Engagement

ISSN : 2597-4777 (Online) - ISSN : 2597-4742 (Print)

This work is licensed under a Creative Commons Attrib ution-ShareAlike 4.0 International License.

7. Communicating regularly with the community so as to gain and retain their support:

Transparency is vital for the success of an economic gardening strategy. Regular progress reports should be given to interested members of the community so that they are aware of what is going on, and the expected benefits and challenges that are being dealt with. Businesses who have been successful due to the strategy should be used as spokespeople in such public presentations so that their testimonies can prove to other businesses that economic gardening is a strategy they should fully embrace, support and be a part of. In addition to testimonies, tangible economic and quality of life indicators should be presented to show the positive impact the economic gardening strategy has had on the economy. Examples of these indicators include number of new jobs created, number of new businesses formed, increased local government revenue and increase in average wages. (Barrios \& Barrios, 2004; Blackwell \& Coltman, 2007; Leavitt et al.,, 2010).

\section{Obstacles:}

Two main obstacles were identified that will hinder the development and implementation of an economic gardening strategy.

1. Lack of political will: For an economic gardening strategy to be successful, the political leadership of the local government have to be fully committed to investing the necessary time and resources. The problem is that the benefits of economic gardening are long-term, and not as flashy as the business attraction strategy whereby a big, well-known company comes to town, thus granting local government officials political visibility and credibility amongst their constituents at least in the short-term. Ultimately it is up to the people of the community to elect officials who are truly committed to the long-term development and prosperity of the community (Barrios \& Barrios, 2004; Girdwood \& Girdwood, 2011)

2. Lack of cooperation amongst local businesses: A key ingredient for successful economic gardening is cooperation amongst the local businesses. Sometimes, these businesses find it difficult to cooperate after years of competing against one another (Yamamoto, 2007; Roosevelt, 2013).

\section{DEVELOPING THE ECONOMIC GARDENING ROADMAP}

In developing an economic gardening roadmap for the local government, we adopted the seven steps identified in the review of relevant scholarship. In the subsequent paragraphs we discuss the progress we have made so far in each step of the roadmap, and the potential challenges we are likely to face in successfully implementing an economic gardening strategy in the chosen local government.

1. Working hand-in-hand with local government officials and other stakeholders:

As mentioned by previous economic gardening scholars, the commitment and cooperation of local government officials is absolutely essential for the success of an economic gardening strategy. As Barrios and Barrios (2004) put it, there is no point in attempting an economic gardening strategy if there is no buy-in by local government officials. From a Nigerian context, the lack of political will by those in charge has been the death knell of many an economic 


\section{THE SPIRIT OF SOCIETY JOURNAL}

International Joumal of Society Development and Engagement

ISSN : 2597-4777 (Online) - ISSN : 2597-4742 (Print)

This work is licensed under a Creative Commons Attrib ution-ShareAlike 4.0 International License.

development strategy. The politicians make many claims about what they will do to improve the lives of Nigerians, but it is almost always mere rhetoric meant to deceive the masses. However, in this case, the local government officials are the ones that sought our team out to help them find innovative ways to maximize their internally-generated revenues. This unusually proactive approach from the local government officials gives us a glimmer of hope that they are committed to actually developing and implementing an economic gardening strategy that will improve the people's lives. The reality is that time will tell whether their commitment is sincere, especially when it comes to the crucial issue of providing financial resources.

2. Identifying the community's assets:

To accomplish this important step, we intend to send some team members to the local government to conduct a comprehensive inventory of the assets within the community. We already know that the local government has a lot of arable land, and thus agriculture is an avenue we intend to actively pursue. The inventory will also focus on the other natural resources available within the local government. Regarding human assets, the key occupations and businesses that have thrived in the community will be identified, and some important stakeholders will be interviewed in order for us to gain more insight on the workings of the local government.

3. Developing a collaborative effort amongst all stakeholders:

In another encouraging move, the state government has actually established a committee made up of political and business representatives of all the local governments in the state with their mandate being the development of viable economic development strategies that will lead to an improvement in the lives of the inhabitants of these local governments. Our team leader is one of the development consultants on the committee, and his feedback to us is that there seems to be a genuine desire by the local government stakeholders to develop a strategy that maximizes the human and natural assets that each community possesses. As it relates to the local government of concern in this paper, during our inventory of the community's assets, we intend to hold meetings with key businesspeople and other people of influence within the community in order to listen to their suggestions and thus garner support for the implementation of an economic gardening strategy.

4. Developing a clear and transparent operating agreement:

At present, we have not reached the point of developing an operating agreement, as the actual strategy to be implemented has not been agreed upon yet. However, if things progress smoothly, this agreement will be developed by members of the committee, with a special emphasis on how decisions will be made, and how funding will be attained and utilized. As mentioned previously, the issue of funding is our greatest concern. Previous experiences with governments of all levels is that the officials are extremely reluctant to part ways with funds for the execution of programs and initiatives meant to improve the lives of the people of the community. They much prefer that these funds remain with them for their personal use; hopefully this time will be different.

5. Identifying the key targets for services: 


\section{THE SPIRIT OF SOCIETY JOURNAL}

International Joumal of Society Development and Engagement

ISSN : 2597-4777 (Online) - ISSN : 2597-4742 (Print)

This work is licensed under a Creative Commons Attrib ution-ShareAlike 4.0 International License.

Unlike economic gardening experiences in developed countries that had the luxury of only targeting second-stage companies with growth potential, we do not have that choice. Whatever businesses are identified in the community will be the target for our services. In order to maximize the impact of these services, we intend to cluster similar businesses into cooperatives which hopefully will lead to an economies of scale and a more efficient use of resources.

6. Developing an effective way to deliver these services:

As identified in the review section of this paper, information, infrastructure and connections serve as the building blocks of an effective economic gardening strategy. Regarding information, previous experience with small and medium-sized businesses operating within the state revealed that a lot of these entrepreneurs lack some basic business skills such as systematic accounting and effective marketing and pricing strategies. To address these deficiencies, we intend to conduct several training sessions with various groups of business owners in the local government utilizing an experiential entrepreneurship training system known as the Competency Based Economies through the Formation of Enterprise (CEFE). CEFE utilizes innovative exercises that involve active participation from the trainees with the ultimate objective being to provide these businesspeople with the requisite skills needed to thrive in their respective businesses. Another strategy we intend to embark upon is to critically examine the business processes of the various business clusters identified during our inventory of assets of the local government. This examination will enable us to identify inefficiencies within the businesses which can be minimized and also where value can be added to the final products so as to improve their attraction to markets within and outside the state.

Regarding connections, we have mentioned in a previous section that we intend to cluster similar businesses into cooperatives so as to improve efficiencies, take advantage of economies of scale, facilitate knowledge sharing amongst these similar businesses, and hopefully lead to the production of a much higher quality of products so that they can command a higher price in domestic and international markets. In addition, a supply chain will be developed whereby complementary businesses are connected, so that the raw material and service demands of some clusters of businesses can be satisfied by another cluster of businesses. These kinds of collaborations will strengthen the business networks within the local government, and hopefully build a synergistic business atmosphere where businesses thrive through cooperation.

It is the area of infrastructure where a tremendous obstacle lies in the successful implementation of an economic gardening strategy in the local government. This obstacle is second only to that of a lack of political will amongst local government officials. The harsh reality is that Nigeria as a whole lacks the basic infrastructure necessary for businesses to survive, let alone grow and thrive; electricity supply is epileptic at best, and pipe-borne water is basically nonexistent; the roads are death-traps with accidents happening on an almost daily basis; the health care and educational systems are an absolute eye-sore with seemingly no hope of development on the horizon. These problems are compounded at the local government level, and we must 


\section{THE SPIRIT OF SOCIETY JOURNAL}

International Joumal of Society Development and Engagement

ISSN : 2597-4777 (Online) - ISSN : 2597-4742 (Print)

This work is licensed under a Creative Commons Attrib ution-ShareAlike 4.0 International License.

honestly admit that we have grave concerns about overcoming this obstacle. However, in an attempt to mitigate these huge deficiencies in basic infrastructure, we are in talks with an international solar company for the establishment of a solar farm in the local government, after receiving approval from the local government officials. Fortunately, land is a resource which the local government has plenty of, and our hope is that with the establishment of a solar farm via a public-private partnership with the international solar company, the huge problem on inadequate electricity will be resolved. This will lead to resolving other infrastructure issues such as pipeborne water, as solar boreholes can be built as an alternative. Having constant electricity will give businesses in the local government a huge competitive advantage over other businesses in other neighboring local governments and states, and will hopefully facilitate the successful implementation of the economic gardening strategy. The revenue raised from the PPP agreement will also enable the local government to address other infrastructure concerns such as proper health facilities and safe roads. We have no doubt that this is an extremely optimistic outlook, but as the saying goes, "hope springs eternal".

8. Communicating regularly with the community so as to gain and retain their support:

We are big believers in the notion that transparency is absolutely necessary if the economic gardening strategy is to be successful. People need to know how the local government's finances are been spent vis-à-vis the implementation of the strategy, and the fruits of the strategy. To achieve this, we intend to host regular town hall meetings so as to give interested stakeholders a progress report on the implementation of the strategy. This will be in addition to progress reports handed regularly to the local government officials for their records. In these progress reports, economic and quality of life indicators such as revenues generated and new jobs created will be included. In addition, interviews will be held with participating business owners who will be asked to give their candid views on whether or not their lives have improved since the inception of the economic gardening strategy. Their recommendations on areas of improvement will also be taken into consideration, and all these will be included in oral and written progress reports. The hope is that if this economic gardening strategy is successful in this local government, it will serve as an impetus for other local governments in the state and beyond to adopt such an economic development strategy.

\section{CONCLUSION}

The ultimate objective of any economic development strategy should be to improve the quality of life of the inhabitants of the community. For many Nigerian local governments, the traditional economic development strategy of business attraction is not a viable one as they do not possess the financial might or infrastructure necessary to compete with urban cities in attracting these big companies. In order for elected local government officials to fulfil their mandate of improving the lives of their constituents, it is vital that they seek for a viable and alternative economic development strategy; economic gardening represents a potential solution. This strategy looks to identify local businesses and provide them with the information, infrastructure and connections they need to grow and thrive within and beyond the local government. The success of this strategy 


\section{THE SPIRIT OF SOCIETY JOURNAL}

International Joumal of Society Development and Engagement

ISSN : 2597-4777 (Online) - ISSN : 2597-4742 (Print)

This work is licensed under a Creative Commons Attrib ution-ShareAlike 4.0 International License.

was evidenced in Colorado and other cities in America and beyond (Barrios \& Barrios, 2004; Yamamoto, 2007). This paper described the seven-step process used to chart a roadmap for the development and future implementation of an economic gardening strategy in a Nigerian local government. A lack of political will and a lack of adequate infrastructure were identified as the two major obstacles to the successful implementation of such a strategy. However, it was concluded that despite these tremendous obstacles it was absolutely crucial that an economic gardening strategy be developed and implemented if the local government was to progress from its current status as a desolate place where its citizens are barely surviving to a thriving business environment with a happy and productive populace. As the saying goes, "Rome was not built in a day".

\section{REFERENCES}

Adhikari, R. P., Bonney, L., Woods, M., Clark, S., Coates, L., Harwood, A., ... \& Miles, M. P. (2018). Applying a community entrepreneurship development framework to rural regional development. Small Enterprise Research, 25(3), 257-275.

Adua, L., \& Lobao, L. (2015). Business Attraction and Redistribution by US Local Governments: To What Extent Is There a Zero-sum Relationship between Business and Citizens' Interests?. State and Local Government Review, 47(4), 223-239.

Arku, G. (2014). Competition and cooperation in economic development: Examining the perceptions of practitioners in Ontario, Canada. Journal of Urban Affairs, 36(1), 99118.

Assenza, P. (2016). Identifying Fertile Ground: Peripheral Stakeholder Contribution to a Healthy Entrepreneurial Ecosystem. Journal of Business and Entrepreneurship, 28(1), 31.

Barrios, S., \& Barrios, D. (2004). Reconsidering economic development: The prospects for economic gardening. Public Administration Quarterly, 70-101.

Blackwell, A., \& Coltman, T. (2007). Economic Gardening in Australia: Measuring Attitudes towards Growth. Australian and New Zealand Academy of Management, Sydney, 114.

Boskov, T. (2018). EU Market Perspectives for Macedonian Companies. IJIBM International Journal of Information, Business and Management, 10(2), 115-122.

Braun, P., Harman, J., \& Paton, F. (2014). Economic gardening: Capacity building for stronger regions. Journal of Economic and Social Policy, 16(1), 1-25.

Braun, P., Harman, J., \& Paton, F. (2014). Economic gardening: Capacity building for stronger regions. Journal of Economic \& Social Policy, 16(1), 177.

Carvalho, J. M., Costa, R. V., Marnoto, S., Sousa, C. A., \& Vieira, J. C. (2018). Toward a Resource-Based View of City Quality: A New Framework. Growth and Change, 49(2), 266-285.

Cecere, G., \& Mazzanti, M. (2017). Green jobs and eco-innovations in European SMEs. Resource and Energy Economics, 49, 86-98.

Cleave, E., Arku, G., \& Chatwin, M. (2019). One step forward, two steps back? Consultant influence on local economic development policy in Canada. Canadian Public 


\section{THE SPIRIT OF SOCIETY JOURNAL}

International Joumal of Society Development and Engagement

ISSN : 2597-4777 (Online) - ISSN : 2597-4742 (Print)

This work is licensed under a Creative Commons Attrib ution-ShareAlike 4.0 International License.

Administration.

Retrieved

from

https://onlinelibrary.wiley.com/doi/abs/10.1111/capa.12299

Conroy, T., Deller, S., \& Tsvetkova, A. (2016). Regional business climate and interstate manufacturing relocation decisions. Regional Science and Urban Economics, 60, 155-168.

Corbett, M. (2015). Towards a rural sociological imagination: Ethnography and schooling in mobile modernity. Ethnography and education, 10(3), 263-277.

Cordoba, G. F. (2019). Does the recognition of indigenous territories impact household economic situations? Evidence from western Panama. Journal of Comparative Economics, 47(1), 225-237.

Cowell, M., Lyon-Hill, S., \& Tate, S. (2018). It takes all kinds: understanding diverse entrepreneurial ecosystems. Journal of Enterprising Communities: People and Places in the Global Economy, 12(2), 178-198.

Engbers, T. A., \& Rubin, B. M. (2018). Theory to Practice: Policy Recommendations for Fostering Economic Development through Social Capital. Public Administration Review, 78(4), 567-578.

Gibbons, C. (2010). Economic Gardening. Economic Development Journal,9(3), 5-11.

Girdwood, J., \& Girdwood, C. (2011). Economic Gardening and Business Incubation: Modern Municipal Economic Growth and Development Strategies. Mid-Continent Regional Science Association, 22-32.

Ha, H., \& Feiock, R. C. (2012). Bargaining, networks, and management of municipal development subsidies. The American Review of Public Administration, 42(4), 481-497.

Hancks, J. W. (2012). Rural public libraries' role in community economic development. Public Library Quarterly, 31(3), 220-236.

Hultquist, A., Harsell, D. M., Wood, R. S., \& Flynn, D. T. (2017). Assessing the impacts of transaction costs and rapid growth on local government service provision and delivery arrangement choices in North Dakota. Journal of rural studies, 53, 14-25.

Kirkpatrick, J. B., \& Davison, A. (2018). Home-grown: Gardens, practices and motivations in urban domestic vegetable production. Landscape and Urban Planning, 170, $24-33$.

Lamb, W. B., \& Sherman, H. (2010). Developing high-growth businesses in rural areas: A study of four US States. New England Journal of Entrepreneurship, 13(2), 9-19.

Leavitt, L. L., Hamilton-Pennell, C., \& Fails, B. (2010). An economic gardening pilot project in Michigan: Libraries and economic development agencies collaborating to promote entrepreneurship. Journal of Business \& Finance Librarianship, 15(3-4), 208-219.

Leviten-Reid, C., \& Parker, B. (2018). Left out? Housing insecurity for one-person, low-income, non-senior households in Cape Breton Regional Municipality. The Canadian Geographer/Le Géographe canadien, 62(4), 470-481.

Lin, D., Allan, A., \& Cui, J. (2017). Sub-centres, socio-economic characteristics and commuting: A case study and its implications. International Journal of Urban Sciences, 21(2), 147171. 


\section{THE SPIRIT OF SOCIETY JOURNAL}

International Joumal of Society Development and Engagement

ISSN : 2597-4777 (Online) - ISSN : 2597-4742 (Print)

This work is licensed under a Creative Commons Attrib ution-ShareAlike 4.0 International License.

Markley, D. M., Lyons, T. S., \& Macke, D. W. (2015). Creating entrepreneurial communities: building community capacity for ecosystem development. Community development, 46(5), 580-598.

Miles, M. P., \& Morrison, M. (2018). An effectual leadership perspective for developing rural entrepreneurial ecosystems. Small Business Economics, 1-17.

Minchin, T. J. (2018). Labor rights are civil rights: inter-racial unionism and the struggle to unionize Nissan in Canton, Mississippi. Labor History, 59(6), 720-745.

Minter, J. (2012). Economic Gardening: Mapping Fertile Gardens. Retrieved from https://smartech.gatech.edu/bitstream/handle/1853/43471/JohnMinter Economic\%2 0Gardening.pdf

Monnat, S. M., \& Brown, D. L. (2017). More than a Rural Revolt: Landscapes of Despair and the 2016 Presidential Election. Journal of rural studies, 55, 227-236.

Ness, G. (2013). Economic Gardening as a Tool of Economic Development. Retrieved from http://www.cola.kku.ac.th/main2/images/POR/book online/Public Management.pdf\# page $=21$.

Norris, L. (2019). Urban prototypes: Growing local circular cloth economies. Business History, 61(1), 205-224.

North, P. (2014). Ten square miles surrounded by reality? Materialising alternative economies using local currencies. Antipode, 46(1), 246-265.

Overbey, T. A. (2019). Food Deserts, Libraries, and Urban Communities: What Is the Connection?. Public Library Quarterly, 1-13.

Patton, M. A., Patton, H. L., \& Dobish, H. (Challenges in Developing or Attracting New Entrepreneurs to "Un-Glamorous" Communities: A Rescue Plan Based in Internal Economic Gardening.

Perera, D., \& Chand, P. (2015). Issues in the adoption of international financial reporting standards (IFRS) for small and medium-sized enterprises (SMES). Advances in accounting, 31(1), 165-178.

Peter, A. S. (2017). Cyber resilience preparedness of Africa's top-12 emerging economies. International Journal of Critical Infrastructure Protection, 17, 49-59.

Pochert, R. (2010). Economic Gardening Helps Com-munities Grow Their Own Jobs. Retrieved from http://opportunityseized.com/pdf/wp-gardening.pdf

Prijatelj, C. (2013). Superintendents as a Catalyst of Economic Development: Academic Excellence vs. Economic Gardening (Doctoral dissertation). Retrieved from http://dscholarship.pitt.edu/17636/1/prijateljc etdPitt2013.pdf

Robbins, L. W., \& Allen IV, J. E. (2015). Economic Gardening and the Grow Kentucky Program. Retrieved from http://www.uky.edu/Ag/AgriculturalEconomics/pubs/extgrowkyeg57.pdf

Roberts, J., Hudspeth, P., Lay, C., \& Ruiz, M. (2012). The Suitability and Opportunity for an Economic Gardening Program for Rural Lane County. Retrieved from http://lanemetro.com/workspace/upload/pdf/Economic\%20Gardening\%20Report\%2 02012.pdf 


\section{THE SPIRIT OF SOCIETY JOURNAL}

International Joumal of Society Development and Engagement

ISSN : 2597-4777 (Online) - ISSN : 2597-4742 (Print)

This work is licensed under a Creative Commons Attrib ution-ShareAlike 4.0 International License.

Roosevelt, E. (2013). Toward a Sustainable Community. Retrieved from http://www.epcounty.com/rsted/documents/SustainabilityToolkit2013Volume2.pdf

Shetty, A. J. K., \& Vasanthi, M. K. (2019). Micro Finance: An Emerging Horizon of Inclusive Growth. Social Science and Humanities Journal, 801-808.

Taabazuing, M., Arku, G., \& Mkandawire, P. (2015). Economic development approaches in a changing global economy: what do practitioners think?. Urban Research \& Practice, 8(2), 145-164.

Wang, J. (2018). Strategic interaction and economic development incentives policy: Evidence from US States. Regional Science and Urban Economics, 68, 249-259.

Whittemore, A. H., \& BenDor, T. K. (2018). Talking about density: An empirical investigation of framing. Land use policy, 72, 181-191.

Yamamoto, T. (2007, January). East meets west in an entrepreneurial farming village in Japan: endogenous development theories and economic gardening practices. Retrieved from http://www.thebhc.org/sites/default/files/yamamoto.pdf

Yi Hsieh, J. (2011). A multilevel growth assessment of the diffusion of management innovation nested in state levels: The case of US local economic development programs. Innovation, 13(1), 2-19.

Zeier, K., Plimmer, G., \& Franken, E. (2018). Developing shared leadership in a public organisation: Processes, paradoxes and consequences. Journal of Management \& Organization, 1-18. 